\title{
EFFECT OF DIFFERENT ENERGY LEVELS ON GROWTH, CARCASS TRAITS , BODY COMPOSITION AND DIGESTIBILITY OF NUTRIENT IN AWASSI LAMBS
}

\section{CH. A. M. Yateem ${ }^{1}$}

Researcher

\author{
J. E. Alkass ${ }^{2}$
}

Prof.
K. N. Mustafa ${ }^{2}$

Assist. Prof.

${ }^{1}$ Minister of Agricultural \& Water Resources, General Directorate of Agriculture, Duhok.

${ }^{2}$ College of Agricultural Engineering Sciences, University of Duhok.

Cheya_amedi@yahoo.com nljealkas2001@yahoo.com

kamal.noman@uod.ac

\section{ABSTRACT}

This experiment was designed to investigate the effect of different level of energy on growth, carcass traits, body composition, digestibility and some blood parameters. Twenty one Awassi lambs (4 month old and $23 \mathrm{~kg}$ body weight) were used and after 10 days of adaptation, the lambs were divided equally and randomly and penned individually into three treatment groups, and fed ad lib on low (10.8 $\left.\mathrm{T}_{1}\right)$ medium (11.6 $\left.\mathrm{T}_{2}\right)$ and high $\left(12.3 \mathrm{~T}_{3} \mathrm{MJ} / \mathrm{kg} \mathrm{DM}\right)$. After 72 days of fattening, 5 lambs from each treatment were chosen and slaughtered. Results revealed that lambs of $\mathbf{T}_{3}$ had numerically higher daily gain (189.72 g), lower dry matter intake (849.46 g), higher feed efficiency (4.7), higher dressing percentage (48.43) and a significant increase $(\mathrm{P} \leq \mathbf{0 . 0 5})$ was noticed in dry matter, organic matter, crude protein, nitrogen free extract and total digestible nutrient as compared with lambs received low or medium level of energy. It could be concluded that the high dietary energy produce the best performance, nutrient digestion and carcass trait of lambs.

Keywords: metabolizable energy, growth performance, carcass characteristics, awassi.

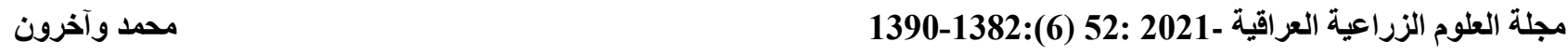
تأثير مستويات مختلفة من الطاقة في النمو, صفات الأبيحة, تركيب الجسم و معامل الهظم للحملان
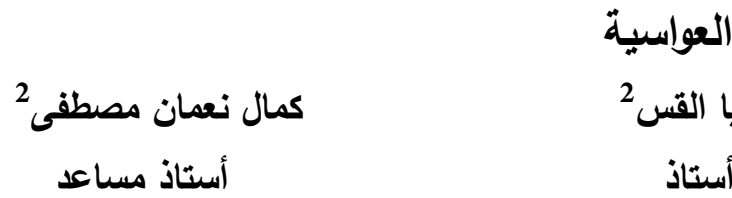
جلال اليا القس2

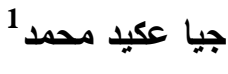
أستاذ مساعد
أستاذ
باحث

\section{1وزارة الزراعة والموارد المائية, المديرية العامة للزراعة, دهوك}

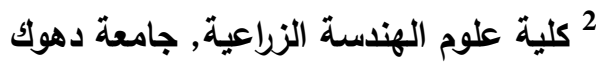

| (المستخلص

تم تصميم هذه التجرية لاراسة تأثير مستويات مختلفة من الطاقة في النمو, صفات الذبيحة, تركيب الجسم, معامل الهظم و بعض الصفات الاموية للحملان العواسية, بعد فترة تمهيدية امدها عشرة ايام, تم توزيع 21 حمل عواسي بعمر 4 اشهر و و وزون 23 كفيلة كفم بصورة متساوية و عشوائيا الى ثلاثة مجاميع لتتظى على مستوى واطىع (10.8), متوسط (11.6) و عالي (12.3 ميكا جول/ كفم مادة

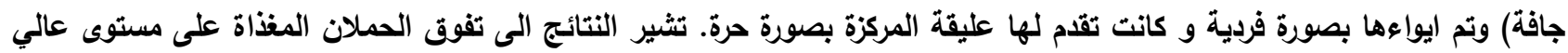

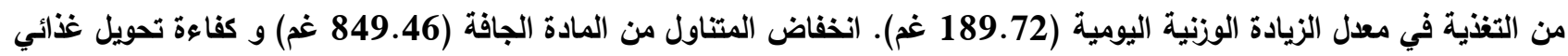
اعلى (4.7) واعلى نسبة تصافي (48.43) الا ان الفروقات لم تكن معنوية. كما تبين بأن الحملان المغذاة على مستوى اعلى من الطاقة قد تفوقت على نظيراتها المغذاة على مستوى واطىء او متوسط في معامل هضم المادة الجافة, المادة العضوية, البروتين الخام,

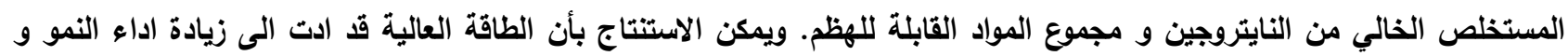
صفات الذبيحة و هظم المواد الغذائية. الكلمات المفتاحية: الطاقة المتأيضة, اداء النمو, صفات الذبيحة, العواسي. 


\section{INTRODUCTION}

In Iraq, sheep are considered the most important farm animals, and an enormous share of income come from the sale of lambs. Nevertheless their importance is further enhanced because they are the most suitable farm animals to the extensive area of arid and semi- arid of the country, as well as, the major sources of livelihood for the rural inhabitants of the area (5). It is known that a number of factors affected growth performance, the quality and quantity of the carcass as well as productivity in sheep marketing (23). Moreover, it is well documented that proper growth and development of growing lambs depends heavily on the animals level of nutrition (30) in which energy is considered the major dietary element that is responsible for the efficient utilization of nutrient and thereby the productivity and gain of an animal (19). It have been indicated that increasing dietary energy level generally can improve the daily gain and feed efficiency of sheep $(15,19)$, and most are in accordance that feed intake increased with increasing protein level and decreased with increasing energy level (3). Also, it have been shown that the amount of tissue deposited as carcass components is largely determined by the level of protein intake and the energy available for retention in muscle (10). Since there is a limited research on energy requirements for fattening Awassi lambs, therefor, the objective of this study was to explore the fattening performance, carcass traits and composition in response to different energy level.

\section{MATERIALS AND METHODS}

The present experiment was conducted at animal farm, College of Agricultural Engineering Sciences, University of Duhok, where 21 weaned Awassi ram lambs (4 month) with an average live body weight of 23.55 \pm $0.34 \mathrm{~kg}$ were used. Following an adaptation period for 10 days, the lambs were randomly and equally allocated and individually penned $(1 \times 2 \mathrm{~m})$ into three treatment groups and fed concentrate ad-lib containing $10.9\left(\mathrm{~T}_{1}\right), 11.7$ $\left(\mathrm{T}_{2}\right)$ and $12.3\left(\mathrm{~T}_{3}\right) \mathrm{MJ} / \mathrm{kg}$ (Table 1). The offered concentrate was weighed daily, and the refusal was collected and weighed before morning feeding. Clean water was available constantly.

Table 1. The ingredient and chemical composition of the diet.

\begin{tabular}{|c|c|c|c|}
\hline Ingredient \% & $\mathbf{T}_{1}$ & $\mathbf{T}_{2}$ & $\mathbf{T}_{3}$ \\
\hline Barley & 52 & 52 & 52 \\
\hline Corn & 1.5 & 11 & 20 \\
\hline Wheat bran & 11 & 14 & 8 \\
\hline Wheat straw & 23 & 8.5 & 4.25 \\
\hline Soybean meal & 10 & 11 & 10 \\
\hline Urea & 0.5 & $\mathbf{0}$ & 0.25 \\
\hline Oil & $\mathbf{0}$ & 1.5 & 3.5 \\
\hline Salt & 1 & 1 & 1 \\
\hline Mineral \& Vitamin & 0.5 & 0.5 & 0.5 \\
\hline Limestone & 0.5 & 0.5 & 0.5 \\
\hline Total & 100 & 100 & 100 \\
\hline \multicolumn{4}{|c|}{ Chemical composition $^{1} \mathrm{~g} / \mathrm{kg}$ DM } \\
\hline Dry matter & 918 & 912 & 911 \\
\hline Organic matter & 957.1 & 968.2 & 973 \\
\hline Ash & 42.9 & 31.8 & 27 \\
\hline Crude protein & 141.4 & 141 & 140.9 \\
\hline Ether Extract & 11.3 & 26.6 & 48.8 \\
\hline Crude fiber & 132 & 84.3 & 64 \\
\hline $\begin{array}{l}\text { Nitrogen Free } \\
\text { Extract }^{2}\end{array}$ & 589 & 628 & 631.3 \\
\hline $\begin{array}{l}\text { Metabolizable } \\
\text { Energy }^{3}\end{array}$ & 10.9 & 11.7 & 12.3 \\
\hline
\end{tabular}

$\mathrm{T}_{1}=$ Treatment 1 (Low energy)

$\mathrm{T}_{2}=$ Treatment 2 (Medium energy)

$\mathrm{T}_{3}=$ Treatment 3 (High energy)

Chemical composition ${ }^{1}$ (AOAC, 2007)

$\mathrm{NFE}^{2}=1000-($ water $+\mathrm{Ash}+\mathrm{CP}+\mathrm{EE}+\mathrm{CF})$.

$\mathrm{ME}^{3} \mathrm{MJ} / \mathrm{kg} \mathrm{DM}=\left[\left(\mathrm{CP}^{*} 0.012\right)+\left(\mathrm{EE}^{*} 0.031\right)\right.$

$\left.+\left(\mathrm{CF}^{*} 0,005\right)+\left(\mathrm{NFE}^{*} 0.014\right)\right](\mathrm{MAFF}, 1975)$.

After 72 days of fattening, five lambs per group were chosen randomly and slaughtered.

Feed was withdrawal over might and lambs were slaughtered according to muslim (Halal) way by severing the throat and major blood vessels in the neck. Immediately after skinning was completed, non- carcass components such 
as head, skin, feet, liver, spleen, heart, lung with trachea and testes were weighed. Dressed carcass was weighed within $1 \mathrm{~h}$. The gastrointestinal tract was weighed, and then emptied of their content, washed and re-weighed to facilitate calculation of empty body weight by subtracting the weight of gut content from slaughter weight. Also weight of omental, mesenteric and cardiac fat was recorded.

\section{Carcass measurements}

Following chilling the carcass at $4^{\circ} \mathrm{c}$ for $24 \mathrm{~h}$, cold carcass was weighed and kidney and pelvic fat was weighed separately. The carcass was split along the vertebral column into two halves, using an electrical saw. The right half was separated into eight whole sale cuts. The cross- sectional area of L.dorsi muscle between 12 and 13 ribs was traced of the cutting and the area was subsequently measured by digital planimeter. Fat thickness over the midpoint of L. dorsi muscle was recorded by using Caliper device.

\section{Physical dissection}

All separated whole cuts of the right half carcass were dissected completely into lean, fat and bone. The three components were weighed separately to determine their percentage. Non- carcass fat is the sum of the omental, mesenteric, pelvic, kidney and cardiac fat. Carcass fat including subcutaneous and intramuscular fat was separated from each cut and weighed.

\section{Apparent digestibility}

For digestibility trail, 3 lambs in each group were placed in individual pens $(1 \times 2 \mathrm{~m})$ at the end of last week of experiment. Total fecal output was determined for 7- days. Each animal feces was weighed daily and $10 \%$ of weighed taken and frozen. Feces sample was analysis according to AOAC (9).

\section{Statistical analyses}

The experiment was designed by complete randomized design CRD. Data was analyzed statistically using general linear model procedures within SAS (29). Duncan (14) multiple range test was used to test difference between treatments.

\section{RESULTS AND DISCUSSION}

\section{Growth performance}

The overall mean of daily gain in weight was $169.62 \pm 14.77 \mathrm{gm}$. (Table 2). The average daily gain recorded in the present investigation is almost comparable with those obtained earlier for the same breed by Alkass (6), Alkass (8) and Rashid (27). However, the average daily gain obtained herein is lower than those recorded by Alkass and Kak (7) and Alkass and Hassan (4). Such finding could be due to variation in genetic makeup as well as environmental factors and feeding practices in particularly. It appear from Table 2 that lambs fed a diet containing high energy level $\left(\mathrm{T}_{3}\right)$ had numerically higher gain (189.72 gm.), lower dry matter intake (849.46 gm.) and are more efficient in converting feed to gain (4.70 $\mathrm{Kg} / \mathrm{Kg}$ ) than lambs consumed low $\left(\mathrm{T}_{1}\right)$ or medium dietary energy level $\left(\mathrm{T}_{2}\right)$. Such result may be related to feed intake which is regulated by dietary energy density in ruminants. Metabolizable energy intake, rather than physical fill, appeared to be the dominant factor influencing the dry matter intake (28) which affected directly the passage rate through gastro intestinal tract and then allows the production of more fermentable metabolizable energy for rumen microorganisms resulting in a rise in the synthesis of microbial protein and in the amount of protein available to animal, which may improve gain and quality and quantity of meat (22). Similarly, Rios- Rincon (28), Taha (32) and Hossain (20) demonstrated that energy level had no significant effect on rate of growth in different breeds of sheep and goats. 
Table 2. Effect of different energy level on animal performance

\begin{tabular}{|c|c|c|c|c|}
\hline Trait & Over all mean & $\begin{array}{c}\mathrm{T}_{1} \\
\text { Low energy } \\
10.9 \mathrm{MJ} / \mathrm{kg} \mathrm{DM}\end{array}$ & $\begin{array}{c}\mathrm{T}_{2} \\
\text { Medium energy } \\
\text { 11.7 MJ/kg DM }\end{array}$ & $\begin{array}{c}\mathrm{T}_{\mathbf{3}} \\
\text { High energy } \\
\text { 12.3 MJ/kg DM }\end{array}$ \\
\hline Initial wt./ kg & $23.69 \pm 0.35$ & $23.36 \pm 0.61$ & $23.60 \pm 0.48$ & $24.12 \pm 0.77$ \\
\hline Final Wt./ kg & $35.90 \pm 1.08$ & $33.86 \pm 2.50$ & $36.08 \pm 1.61$ & $37.78 \pm 1.21$ \\
\hline Total gain/ kg & $12.21 \pm 1.06$ & $10.50 \pm 2.40$ & $12.48 \pm 1.60$ & $13.66 \pm 1.49$ \\
\hline Daily gain/g & $169.62 \pm 14.77$ & $145.84 \pm 33.35$ & $173.32 \pm 22.36$ & $189.72 \pm 20.81$ \\
\hline Total DMI/ kg & $65.72 \pm 3.01$ & $69.64 \pm 7.79$ & $66.38 \pm 3.48$ & $61.16 \pm 3.64$ \\
\hline Daily DMI/g & $912.88 \pm 41.83$ & $967.24 \pm 108.19$ & $921.94 \pm 48.40$ & $849.46 \pm 50.62$ \\
\hline FCR kg/kg & $6.26 \pm 0.97$ & $8.60 \pm 2.70$ & $5.58 \pm 0.50$ & $4.70 \pm 0.60$ \\
\hline
\end{tabular}

Carcass traits

Data related to carcass traits of Awassi lambs are summarized in Table 3. It appears that lambs received high energy level had heaviest slaughter weight $(37.78 \mathrm{Kg})$, carcass weight $(18.29 \mathrm{~kg})$, dressing percentage based on slaughter weight $(48.43 \mathrm{~kg})$ and empty body weight $(53.99 \mathrm{~kg})$ than those fed low or medium energy levels. However, the difference among them was not significant. The increase of carcass weight may be due to the higher feed intake and gut fill in lambs fed low level of energy and such increase in dressing percentage could be attributed to higher slaughter and lower gut content in lambs fed high energy level compared with lambs maintained on low or medium level of energy. This finding is supported by the results obtained in sheep by Dabiri (12), Rios- Rincon (28) and Kioumarsi (23) and in goat by Abbasi (1), Taha (32) and Yagoub and Babiker (35) who found that carcass weight and dressing percentage was raised with increasing the energy concentration of the diet. Back fat was slightly thicker in lambs fed a high energy level than lambs fed on low energy level. Such result is in accordance with finding of RiosRincon (28) and Kioumarsi (23) in sheep, Shahjala (31) in goat, Elbukhary (16) in Baggra heifer, who noticed an increase in fat thickness with increasing dietary energy level. The L. muscle dorsi area was significantly $(\mathrm{P}<0.05)$ larger for lambs fed high energy level $\left(11.69 \mathrm{~cm}^{2}\right)$ than lambs fed either medium $\left(10.56 \mathrm{~cm}^{2}\right)$ or low energy level $\left(8.74 \mathrm{~cm}^{2}\right)$. Such difference may be due to the positive correlation with final weight and gain (25). This result is in agreement with those found by Elbukhary (16) and Shahjalal (31).

Carcass composition: The proportion of separable carcass tissue of the carcass side of Awassi lambs fed diet of different energy levels are demonstrated in Table 3. Although the highest mean $(57.38 \%)$ of lean and the lowest mean of bone $(20.93 \%)$ was found in lambs of $\mathrm{T}_{3}$ as compared with $\mathrm{T}_{1}$ and $\mathrm{T}_{2}$ treatments, however, the differences among them was not significant. Fat content of the half carcass was almost the same in the different treatments. These results agreed with the findings in sheep by Dabiri (12) and RiosRicon (28) and in goat by Taha (32) and Yagoub and Babiker (35). Also lean to fat ratio and lean to bone ratio both was not affected significantly by the treatments contained different energy level. This result is in accordance with those obtained by Abdullah and Hussein (2) on goat and Rios- Rincon (28) on lambs. However it is generally agreed that animals full-fed high concentrate diet usually produce more- carcass fat, and consequently, are less efficient in converting feed to lean meat than in animal fed slightly below ad libitum energy intake, even though the ad libitum fed animals would be more efficient in total feed energy retention. This is particularly 
evident in the late stage of growth, as muscle and bone approach their mature size (21).

Table 3. Effect of different energy level on carcass trait and composition

\begin{tabular}{|c|c|c|c|c|}
\hline Trait & Over all mean & $\begin{array}{c}\mathrm{T}_{1} \\
\text { Low energy } \\
10.9 \mathrm{MJ} / \mathrm{kg} \mathrm{DM}\end{array}$ & $\begin{array}{c}\mathrm{T}_{2} \\
\text { Medium energy } \\
11.7 \mathrm{MJ} / \mathrm{kg} \mathrm{DM}\end{array}$ & $\begin{array}{c}\mathrm{T}_{3} \\
\text { High energy } \\
\text { 12.3 MJ/kg DM }\end{array}$ \\
\hline Slaughter weight/ kg & $35.90 \pm 1.08$ & $33.86 \pm 2.50$ & $36.08 \pm 1.61$ & $37.78 \pm 1.21$ \\
\hline Hot carcass weight $\mathrm{kg}$ & $17.13 \pm 0.59$ & $15.78 \pm 1.26$ & $17.31 \pm 0.96$ & $18.29 \pm 0.64$ \\
\hline Cold carcass weight kg & $16.99 \pm 0.59$ & $15.66 \pm 1.26$ & $17.17 \pm 0.96$ & $18.13 \pm 0.63$ \\
\hline Shrinkage percentage & $0.81 \pm 0.05$ & $0.71 \pm 0.10$ & $0.86 \pm 0.11$ & $0.88 \pm 0.08$ \\
\hline Dressing \% (slaughter wt.) & $47.62 \pm 0.43$ & $46.54 \pm 0.75$ & $47.90 \pm 0.67$ & $48.43 \pm 0.70$ \\
\hline Dressing \% (EBW wt.) & $53.58 \pm 0.51$ & $52.95 \pm 1.04$ & $53.80 \pm 0.91$ & $53.99 \pm 0.82$ \\
\hline Rib eye area $\mathrm{cm}^{2}$ & $10.33 \pm 0.49$ & $8.74 \pm 0.66^{b}$ & $10.56 \pm 0.54^{a b}$ & $11.69 \pm 0.87^{a}$ \\
\hline Fat thickness mm & $0.24 \pm 0.01$ & $0.21 \pm 0.03$ & $0.22 \pm 0.01$ & $0.28 \pm 0.04$ \\
\hline Lean & $56.89 \pm 0.94$ & $56.37 \pm 1.32$ & $56.91 \pm 1.98$ & $57.38 \pm 1.88$ \\
\hline Fat & $21.83 \pm 1.02$ & $21.97 \pm 2.13$ & $21.85 \pm 1.93$ & $21.68 \pm 1.65$ \\
\hline Bone & $21.27 \pm 0.56$ & $21.65 \pm 1.13$ & $21.22 \pm 0.48$ & $20.93 \pm 1.31$ \\
\hline Lean : fat ratio & $2.72 \pm 0.18$ & $2.70 \pm 0.36$ & $2.72 \pm 0.34$ & $2.73 \pm 0.30$ \\
\hline Lean : bone ratio & $2.70 \pm 0.09$ & $2.62 \pm 0.12$ & $2.68 \pm 0.12$ & $2.79 \pm 0.23$ \\
\hline
\end{tabular}

Values of ${ }^{a, b, c}$ on the same row with different letters are significant different $(\mathrm{P} \leq \mathbf{0 . 0 5})$

Carcass and non-carcass fat

It is well known that fat is the most variable tissue in the carcass, and it varies not in its total amount but also in its distribution between the various deposits which alter markedly during growth, and the proportion and location of fat in the body are important in meat animals (21). In the present investigation, the total fats, carcass fat, noncarcass fat and fat tail averaged $4.58,1.57$, 0.95 and $2.05 \mathrm{~kg}$, respectively (Table 6). Thus the relative contribution of different fat depots to the total body fat was in the order carcass fat 34.18, non- carcass fat 21.23 and fat tail $44.57 \%$ (Table 6). It appears from Table (5) that the effect of treatment was not significant on both weights of fat and their percentages. Different fat deposits increased by increasing energy level numerically. However, the variation among treatments was very little and the reasons could be due to the age of lamb which is younger than six month and because of slow growth rate, fat is a latter maturing tissue and has less priority for nutrients (18).

Table 5. Effect of different energy level on carcass and non- carcass fat

\begin{tabular}{|c|c|c|c|c|}
\hline Trait & Over all mean & $\begin{array}{c}\mathrm{T}_{1} \\
\text { Low energy } \\
10.9 \mathrm{MJ} / \mathrm{kg} \mathrm{DM}\end{array}$ & $\begin{array}{c}\mathrm{T}_{2} \\
\text { Medium energy } \\
11.7 \mathrm{MJ} / \mathrm{kg} \mathrm{DM}\end{array}$ & $\begin{array}{c}\mathrm{T}_{3} \\
\text { High energy } \\
12.3 \mathrm{MJ} / \mathrm{kg} \mathrm{DM}\end{array}$ \\
\hline Wt. carcass fat/ kg & $1.57 \pm 0.10$ & $1.50 \pm 0.53$ & $1.57 \pm 0.44$ & $1.65 \pm 0.21$ \\
\hline Wt. non- carcass fat/ kg & $0.95 \pm 0.39$ & $0.87 \pm 0.06$ & $0.96 \pm 0.23$ & $1.02 \pm 0.08$ \\
\hline Wt. fat tail/ kg & $2.05 \pm 0.13$ & $1.90 \pm 0.44$ & $2.10 \pm 0.79$ & $2.16 \pm 0.31$ \\
\hline Total body fat/ kg & $4.58 \pm 0.24$ & $4.28 \pm 0.44$ & $4.63 \pm 0.60$ & $4.83 \pm 0.13$ \\
\hline Non- carcass fat \% & $21.23 \pm 0.92$ & $21.17 \pm 2.02$ & $21.39 \pm 1.97$ & $21.14 \pm 0.96$ \\
\hline Carcass fat $\%$ & $34.18 \pm 1.00$ & $34.31 \pm 2.32$ & $34.00 \pm 0.85$ & $34.23 \pm 2.10$ \\
\hline Fat tail \% & $44.57 \pm 0.96$ & $44.51 \pm 1.26$ & $44.60 \pm 2.02$ & $44.61 \pm 2.00$ \\
\hline
\end{tabular}

Apparent digestibility

Digestibility coefficients of nutrient are given in Table 6. It appears from the table a significant $(\mathrm{P}<0.05)$ increase in each of dry matter, organic matter, crude protein, nitrogen free extract and total digestible nutrient and numerically either extract and crude fiber increases with increasing the energy level in the diet. Such increase may be due to the diet contained less coarse material (non-fibrous 
carbohydrates), which either lead to an increase palatability of the diet that rapidly digested by rumen microorganism and resulted in increasing dry matter digestibility, or may be is due to slow rate of passage through gastro- intestinal tract and thus increase exposure time, allow the rumen microorganism to break down the feed particle which lead to an increase digestibility of crude protein and crude fiber. The increase in organic matter digestibility in lambs fed on medium energy $\left(\mathrm{T}_{2}\right)$ and high energy $\left(\mathrm{T}_{3}\right)$ may be attributed to the higher digestibility of dry matter, and organic matter is form the higher portion of dry matter (33), or due to the high rate of passage in lambs fed low energy diet due to higher fiber content in their diet which lead to decrease in digestibility of organic matter (17). Also the increase of ether extract may be due to the diet contained oil in $\mathrm{T}_{2}$ and $\mathrm{T}_{3}$ (Table 1) which improves the ether extract digestibility probably due to the higher fat intake $(13,26)$. Total digestible nutrient was significantly affected by treatment and their values increased by increasing energy level. This increase of total digestible nutrient is due to the increased digestibility of crude protein, crude fiber, ether extract and nitrogen free extract by increasing energy level. These results agree with those found by Costa (11) on Morda nova lamb and Sayed (30) on Sheep.

Table 6. Effect of different energy level on apparent digestibility

\begin{tabular}{|c|c|c|c|c|}
\hline $\begin{array}{c}\text { Digestibility Coefficient } \\
\%\end{array}$ & Over all mean & $\begin{array}{c}\mathrm{T}_{1} \\
\text { Low energy } \\
10.9 \mathrm{MJ} / \mathrm{kg} \mathrm{DM}\end{array}$ & $\begin{array}{c}T_{2} \\
\text { Medium energy } \\
11.7 \mathrm{MJ} / \mathrm{kg} \mathrm{DM}\end{array}$ & $\begin{array}{c}\mathrm{T}_{3} \\
\text { High energy } \\
12.3 \mathrm{MJ} / \mathrm{kg} \mathrm{DM}\end{array}$ \\
\hline Dry matter & $70.16 \pm 1.39$ & $65.76 \pm 1.88^{b}$ & $70.86 \pm 1.55^{a b}$ & $73.86 \pm 0.80^{a}$ \\
\hline Organic matter & $73.27 \pm 1.58$ & $67.75 \pm 1.55^{b}$ & $74.36 \pm 1.38^{a}$ & $77.71 \pm \mathbf{0 . 5 5 ^ { \mathrm { a } }}$ \\
\hline Crude protein & $65.73 \pm 2.48$ & $59.20 \pm 3.63^{b}$ & $66.16 \pm 4.03^{\mathrm{ab}}$ & $71.83 \pm 2.09^{a}$ \\
\hline Crude fiber & $31.07 \pm 2.11$ & $30.33 \pm 3.83$ & $29.13 \pm 4.12$ & $33.76 \pm 4.00$ \\
\hline Ether extract & $64.70 \pm 3.21$ & $58.54 \pm 5.92$ & $61.85 \pm 3.72$ & $73.72 \pm 3.36$ \\
\hline Nitrogen free extract & $81.28 \pm 0.69$ & $79.04 \pm 1.11^{b}$ & $81.76 \pm 0.49^{a}$ & $83.05 \pm 0.22^{a}$ \\
\hline TDN & $66.68 \pm 1.91$ & $60.42 \pm 1.72^{c}$ & $66.84 \pm 1.41^{b}$ & $72.80 \pm 0.73^{a}$ \\
\hline
\end{tabular}

Values of ${ }^{\mathrm{a}, \mathrm{b}, \mathrm{c}}$ on the same row with different letters are significant different $(\mathrm{P} \leq 0.05)$

Blood parameters

The overall means of serum biochemical parameters are presented in (Table 7). It appears no significant effect of treatment on it. Blood biochemical indexes are important indicator that reflects nutritional status and diagnosis of various diseases (34), such as insufficient animal dietary intake can lead to low serum content (36). Therefore, it become clear from the current study, those three treatments were sufficient for normal growth and not affect animal health. Similar results have been reported by Wang (35) on $\mathrm{Hu}$ lambs.

Table 7. Effect of different energy level on blood parameters

\begin{tabular}{|c|c|c|c|c|}
\hline Items & Over all mean & $\begin{array}{c}\mathrm{T}_{1} \\
\text { Low energy } \\
10.9 \mathrm{MJ} / \mathrm{kg} \mathrm{DM}\end{array}$ & $\begin{array}{c}\mathrm{T}_{2} \\
\text { Medium energy } \\
11.7 \mathrm{MJ} / \mathrm{kg} \mathrm{DM}\end{array}$ & $\begin{array}{c}\mathrm{T}_{3} \\
\text { High energy } \\
\text { 12.3 MJ/kg DM }\end{array}$ \\
\hline Glucose mg/dl & $67.40 \pm 2.23$ & $68.50 \pm 4.14$ & $65.85 \pm 4.64$ & $68.00 \pm 3.28$ \\
\hline Total protein g/dl & $6.43 \pm 0.10$ & $6.55 \pm 0.23$ & $6.32 \pm 0.19$ & $6.44 \pm 0.12$ \\
\hline Albumin g/dl & $3.11 \pm 0.07$ & $3.21 \pm 0.17$ & $3.00 \pm 0.13$ & $3.14 \pm 0.08$ \\
\hline Globulin g/dl & $3.32 \pm 0.09$ & $3.33 \pm 0.07$ & $3.32 \pm 0.24$ & $3.31 \pm 0.14$ \\
\hline Cholesterol mg/dl & $58.50 \pm 2.40$ & $59.66 \pm 4.63$ & $56.14 \pm 2.81$ & $59.85 \pm 5.24$ \\
\hline Triglyceride mg/dl & $24.40 \pm 1.25$ & $24.50 \pm 3.34$ & $23.85 \pm 2.14$ & $24.85 \pm 1.22$ \\
\hline Urea mg/dl & $35.50 \pm 1.65$ & $36.50 \pm 2.52$ & $35.00 \pm 3.69$ & $35.14 \pm 2.53$ \\
\hline
\end{tabular}




\section{CONCLUSION}

It could be concluded that Awassi lambs can be finished on diet containing $(12.3 \mathrm{MJ} / \mathrm{kg}$ $\mathrm{DM})$ to achieve better performance, nutrient digestion and carcass trait of lambs.

\section{REFERENCES}

1. Abbasi, R.E., F. Abdollahzadeh, S. Salehi and R. Abdulkarimi 2011. Effect of dietary metabolizable energy and crude protein on feed intake, carcass traits and mohair production by markhoz (Iranian Angora) Male Kids. Global Veterinary. 7(5): 443-448.

2. Abdullah, A.Y. and H.S. Musallam 2007. Effect of different levels of energy on carcass composition and meat quality of male black goats kids. Livestock Science. 107: 7080.

3. Ahmed, B.A. 2003. The Effects of Different Levels of Energy And Protein on Growth and Carcass Composition of Western Baggara Bulls. Ph.D. Dissertation, University Of Khartoum, Sudan.

4. Alkass, J.E. and C.S. Hassan 2014. Growth performance and carcass composition of Karadi, Awassi and their crossbred raised under two feeding levels. Advance J. of Agricultural Research. 2(8): 123-130.

5. Alkass, J.E. and H.F. Kak 2015. Zeranol and breed effects on growth performance and carcass merit and body compositionof lambs. Advance J. of Agricultural Research. 3(4): 42-49.

6. Alkass, J.E. and K.H. Juma 2005. Small ruminant breeds of Iraq. Characterization of small ruminant breeds in west Asia and North Africa (L. Iniquezed). West Asia International center for Agricultural Research in Dry Areas (ICARDA), Aleppo, Syria. 1: 63-101.

7. Alkass, J.E. and K.H. Juma and T.S. Aldoori 1985. Studies on some economic characteristic in Awassi and Arabi sheep. II. Some fattening and carcass traits. WId. Rev. Animal; Production XXI: 61-64.

8. Alkass, J.E., M.A. Tahir, A.A. Alrawi and F.S. Badawi 1987. Performance of crossbred lambs raised under two different feeding regimes. WId. Rev. Animal Production. XXIII: 21-25.

9. AOAC 2007. Official Methods of Analysis. Association of Official Analytical Chemists, Arlington, VA.

10. Baracos, V.E. 2005. Whole animal and tissue proteolysis. In: Biology of metabolism in growing animals III (Ed. D. G. Burrin and H. J. Mersmann). Elsevier Ltd. Oxford, UK. pp. 69-82.

11. Costa, M.R., E.S. Pereira, P.G. Pimentel, A.M. Silva, P.V. paulino, I.Y. Mizubuti, E.L. Ribeiro, A.P. Pinto and D.A. camilo 2013. Effects of dietary energy density on nutrient digestibility, performance and carcass characteristics of Morada Nova lambs. Semina: Ciências Agrárias, Londrina. 34(3): 1389-1398.

12. Dabiri, N. 2016. Effects of different dietary energy and protein levels at fixed slaughter weight on performance and carcass characteristics of arabi fattening lambs. J. of Fisheries Livest Production. 4(4): 1-4.

13. Dos Santos, A.B., M.L. Pereira, H.G. de Oliveira Silva, G.G. de Carvalho, T.C. de Jesus Pereira, L.S. Ribeiro, J.A. Azevêdo, S. M. das Graças Conceição Parada Costa, L.B. Sousa, L.B. Sousa and D. de Oliveira Alencar 2016. Intake, digestibility and performance of lambs fed diets containing peach palm meal. Trop Animal Health Production. 48:509-515.

14. Duncan, C.B. .1955. Multiple range and multiple F test. Biometric 11: 1-12.

15. Ebrahimi, R., H.R. Ahmadi, M.J. Zamiri and E. Rowghani 2007. Effect of energy and protein levels on feedlot performance and carcass characteristics of Mehraban Ram lambs. Pakistan J. of Biological Science. 10(10): 1679-1684.

16. Elbukhary, H.A., I.M. Sharaf Eldin, S.A. Babiker, O.M. Elkhidi and A.O. Idris 2013. Effect of Dietary Energy Level on Performance and Carcass Characteristics of 
Sudan Baggara Heifers. Conference paper, Research gate.net.

17. Fimbres H., J.R. Kawas, G. Hern_andez-Vidal, J.F. Pic_on-Rubio and C.D. Lu 2002. Nutrient intake, digestibility, mastication and ruminal fermentation of lambs fed finishing ration with various forage levels. Small Ruminant Research. 43: 275-281.

18. Hammond, J. 1932. Growth and development of mutton qualities in sheep $2^{\text {nd }}$ ed. Oliver and Boyd. Endin burgh.

19. Hossain, M.E., M. Shahjalal, M.J. Khan and M.S. Hasanat 2003. Effect of Dietary Energy Supplementation on Feed Intake, Growth and Reproductive Performance of Goats under Grazing Condition. J. of nutrition. 2(3): 159-163.

20. Hosseini, S., S. Akbary, N. Maheri-Sis and A.M. Aghsaghali 2008. Effect of different energy levels of diet on feed effecicncy, growth rate and carcass characteristics of fattening Bahmaei lambs. J. of Animal and Veterinaery Advance. 7(12): 1551-1554.

21. Irshad, A., G. Kandeepan, S. Kumar, K.A. Ashish, M.R. Vishuraj and V. Shukla 2013. Factors influncing carcass composition of livestock: a Reivew. J. of Animal Production Advance 3: 177-186.

22. Khorshidi, J.K. 1996. The Effect of Different Level of Energy And Protein On 28. Rios-Rincon, F.G., A. Estrada-Angulo, M.A. Lopez-Soto, B.I. Castro-Perez, J.J. portillo-loera, J.C. Robles-Estrada, J.F. Calderon-Cortes and H. Davila-ramos 2014. Influence of protein and energy level in finishing diets for feedlot hair lambs: growth performance, dietary energetics and carcass characteristics. Asian Australas. J. of Animal Science. 27(1): 55-61.

29. SAS Institute 2007. Statistical Analysis System. STAT/ User's Guide, Release 9.2, SAS Institute, Cary: NC. USA.

30. Sayed, A.N. 2009. Effect of different dietary energy levels on the performance and nutrient digestibility of lambs. Veterinary world. 2(11):418-420.
Growth Rate And Carcass Characteristics Of Kurdish Male Lambs. M.Sc. Thesis, Tehran University, Iran.

23. Kioumarsi, H., K.J. Khorshidi, M. Zahedifar, A.R. Seidavi, S.Z. Mirhosseini and M.R. Taherzadeh 2008. The effect of energy and protein level on performance effecincy and carcass characterestic of Taleshi lambs. Asian J. of Animal and Veterinaery Advance. 3(5): 307-318.

24. MAFF 1975. Energy allowances and feeding systems for ruminants. Technical Bulletin.

25. Magee, W.T., R.H. Nelson, G.A. Branaman and L.J. Bratzler 1958. Some factors affecting carcass grade in steers. Journal of Animal Science. 17: 649-655.

26. Maia, M., I. susin, E. Ferreira, C. Nolli, R. Gentil, A. Pires and G. Mourao 2012. Intake, nutrient apparent digestibility and ruminal constituents of sheep fed diets with canola, sunflower or castor oils. Revista Brasileira de Zootecnia 4(11): 2350-2356.

27. Rashid, N.H., J.E. Alkass, A.A. Aldorri and L.H. Alwan 1987. Growth rate, offals and carcass characteristics of Awassi lambs slaughtered at different weights. Journal of Agricultural Water Resources. 6:27-40.

31. Shahjalal, M.D., H. Galbraith and J. H. Topps 1992. The effect of changes in dietary protein and energy on growth, body composition and mohair bre characteristics of British Angora goats. Animal Production. 54: 405- 412.

32. Taha, S.A., G.K. Katib, M.N. Abdula and N.Y. Abo 2012. Effect of using different levels of energy and protein to fattening kids of Cyprus Shamy goats. J. of anbar for Veterinary Science. 5(1): 224-228.

33. Tillman, A.D., H. Hartadi, S. Reksohadiprodjo, S. Lebdosoekojo and S. Prawirokusumo 1998. The Principal of Feed Animal Science. Gadjah Mada University Press. 
34. Wang, Q., Y. Wang, T. Hussain, C. carcass characteristics of female goat in Dai, J. Li, P. Huang, Y. Li, X. Ding, J. Huang, Sudan. Livestock Research for Rural F. Ji, H. Zhou and H. Yang 2019. Effects of Development.20(12):1-5. dietary energy level on growth performance, 36. Zhelikani, P.K., J.D. Ambrose \& J.J. blood parameters and meat quality in fattening Kennelly 2003. Effect of dietary energy and male Hu lambs. Journal of Animal Physiology and Animal Nutrition. 0: 1-13. protein density on body composition, 35. Yagoub, Y.M. and S.A. Babiker 2008. attainment of puberty, and ovarian follicular dynamics in dairy heifers. Theriogenology, Effect of dietary energy level on growth and 60(4), 707-725. 